\title{
The Decline of Florida Torreya: An Endemic Conifer on the Edge of Extinction ${ }^{1}$
}

\author{
Jason A. Smith and Aaron Trulock ${ }^{2}$
}

\section{Overview}

The Florida torreya (Torreya taxifolia) is a critically endangered conifer endemic to the Apalachicola River drainage of the Florida panhandle and adjacent southern Georgia. Florida torreya has experienced a significant die-off and subsequent decline during the past century. Although the decline has been attributed to numerous abiotic and biotic causes, however, our findings are that the most likely reason for the decline is fungal disease. This fungal disease is likely caused by a Fusarium species and our suggestions for a new understanding of the actual cause of the decline are addressed in this fact sheet. Current efforts to assess the population and develop a recovery plan are discussed.

\section{Introduction}

Florida torreya (a.k.a "gopherwood", "stinking cedar") (Torreya taxifolia Arn.) (Family: Taxaceae) is a federally listed, critically endangered conifer endemic to bluffs and ravines along the Apalachicola River in Gadsden and Liberty Counties in Florida and Decatur County in Georgia (Schwartz, 1993; Baker and Leonard, 1982). Although there are 5 species of Torreya distributed in western North America (T. californica), Japan (T. nucifera) and China ( $T$. fargesii, T. grandis and T. jackii), T. taxifolia is considered the rarest conifer in North America and one of the most endangered in the world (Farjon, 2010).

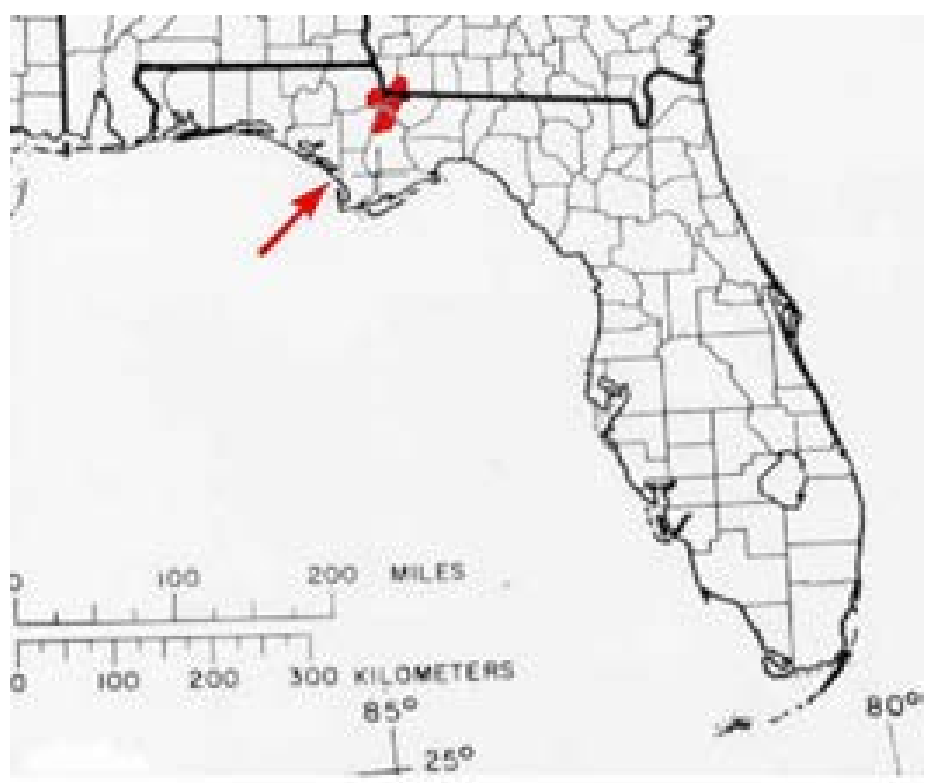

Figure 1. Natural range of Torreya taxifolia (Burns and Honkala, 1990).

1. This document is FOR276, School of Forest Resources and Conservation, UF/IFAS Extension. First published November 2010. Please visit the EDIS website at http://edis.ifas.ufl.edu.

2. Jason Smith, assistant professor, School of Forest Resources and Conservation; and Aaron Trulock, graduate assistant, School of Forest Resources and Conservation; Cooperative Extension Service, Institute of Food and Agricultural Sciences, University of Florida, Gainesville, 32611. 


\section{Description}

The Florida torreya is an evergreen tree that historically has grown to 60 feet and occasionally still reaches this size in cultivation (Fig. 2). It has whorled branches with short, dark green needle-like leaves that are less than 2 inches long, and a canopy spread of up to 20 feet. The tree is described as slow growing with a conical canopy shape. The foliage and female cones (Fig. 3) release a pungent odor and are useful in identification (Barnes, 1983). The remaining population of Florida torreya is found on the bluffs and

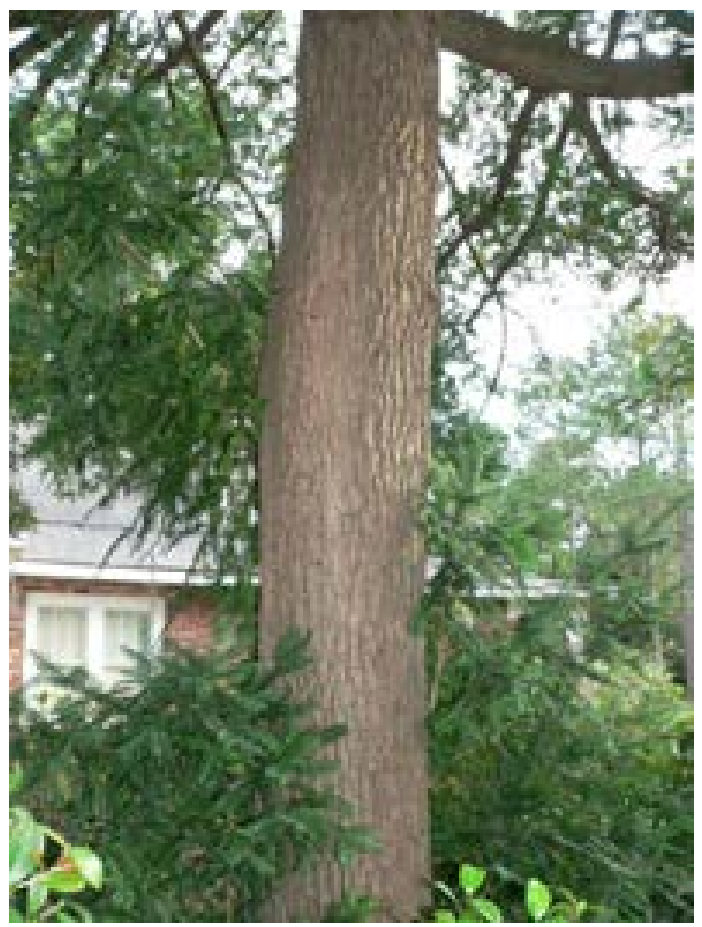

Figure 2. Large healthy cultivated Florida torreya in Madison, Florida.

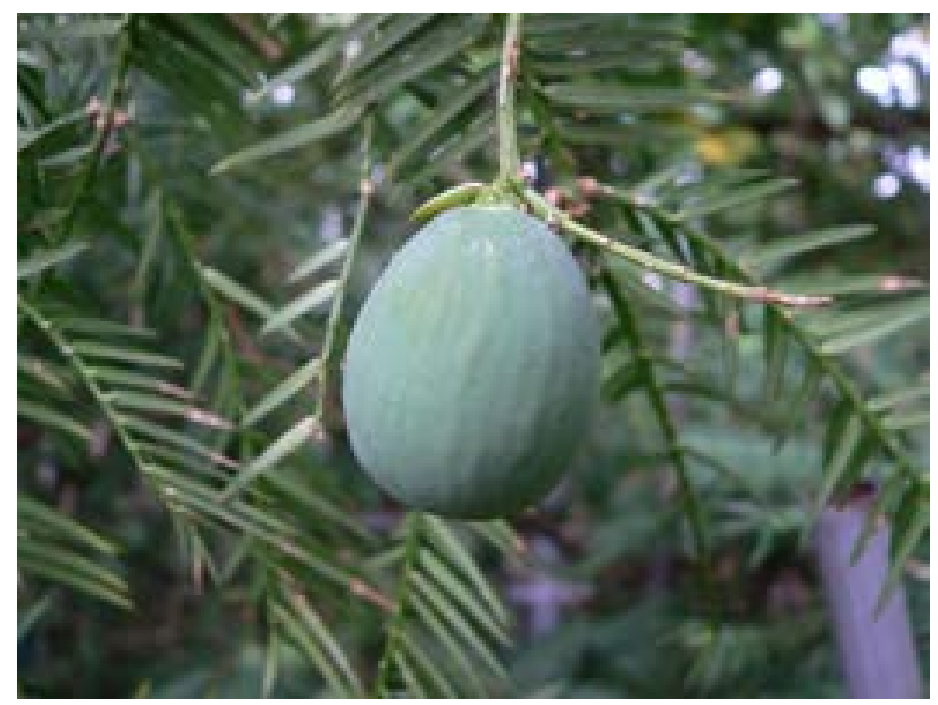

Figure 3. Female cone on a cultivated Florida torreya in Atlanta, Georgia. ravines along the east side of the Apalachicola River. The tree grows naturally in Gadsden and Liberty counties in Florida, and in southern Decatur County, GA. There is also one reported population located west of the Apalachicola River in Jackson County, FL (Stalter, 1984).

In 1983 Torreya taxifolia was listed as an Endangered Species under the 1973 Endangered Species Act (USFWS 1984). Although a recovery plan was promptly organized, many of the objectives are either still ongoing or not initiated (Spector, 2009).

\section{Decline}

Considered a common tree in its restricted habitat until just before WWII, by 1962 Florida torreya had declined so severely that the species was considered to be destined for extinction (Godfrey and Kurz, 1962). The decline of Florida torreya was first observed around 1938 (Alfieri et al., 1967). By the 1960s, no adult individuals could be found and the outlook for the species seemed very bleak (Alfieri et al., 1967). The rapid decline of the species was then attributed to an unknown fungal disease because of the abundance of leaf spots and stem cankers and the rapid nature of the decline (Godfrey and Kurz, 1962). Since then, Florida torreya has continued to decline and in addition to disease, has been subjected to changes in hydrology, forest structure, heavy browsing by deer and a loss of reproductive capability (Schwartz and Hermann, 1995). Despite these challenges, Florida torreya stems which have been killed by disease often re-sprout from the stump in a manner reminiscent of American chestnut following chestnut blight, although seed reproduction has been non-existent for decades in the wild (Schwartz and Hermann, 1999). Estimates show Florida torreya has declined $99 \%$ since pre-settlement population levels, from an estimated population of 357,500 individuals in 1914 to approximately 1,350 in the 1990s (Schwartz et al., 2000). It is believed that the population has declined further since 2000 to current estimates of 400-600 individuals (T. Spector, unpublished data, 2010).

Despite several attempts to conclusively determine the causal agent responsible, disease etiology has not been previously elucidated (Alfieri et al., 1967; Alfieri et al., 1987; El-Gholl, 1985; Lee et al., 1995; and Schwartz et al., 1996). In the first pathology studies conducted on T. taxifolia (Alfieri et al., 1967), it was noted that disease symptoms of leaf spots, needle necrosis, defoliation and stem lesions were common on native and cultivated T. taxifolia. Several pathogens were isolated commonly from symptomatic needles (Macrophoma sp., Rhizoctonia solani, Sphaeropsis sp. and Sclerotium rolfsii), however, no pathogens were 
isolated from cankered stems and Koch's postulates (proof of pathogenicity) were not demonstrated. About 20 years later, El-Gholl (1985) implicated Fusarium lateritium as a causal agent by demonstrating this species' capacity to cause leaf spots, however, the causal agent of the canker disease remained unknown. Alfieri et al. (1987) completed more pathogenicity studies with a Phyllosticta sp., Xylocoremium flabelliforme and F. lateritium. They also completed Koch's postulates with F. lateritium as a leaf spot pathogen, but the canker-causing organism remained elusive. In 1991, Schwartz et al. implicated Pestalotiopsis microspora as the causal agent of the canker disease, having isolated the pathogen from 56 symptomatic plants and completed Koch's postulates on 10 stems. However, no information was given on the canker development, morphology or ability to cause mortality. Typically Pestalotiopsis spp. are considered opportunistic pathogens (Sinclair, 2005). Lee et al. (1995) investigated the endophytic and pathogenic chemical attributes of $P$. microspora infection and artificial inoculations resulted in stem canker development, however, again no stem mortality was observed.

Subsequent studies by Hermann and Schwartz (1997) implicated a Scytalidium sp. due to frequent isolation from cultivated and naturally occurring Florida torreya. Inoculation attempts led to small lesions on needles, but cankers were not observed.

In addition to biotic causes of decline, researchers have looked into changes in soils, drought, global warming, sunlight exposure and fire regime as possible causes of decline (Schwartz et al., 1995). Some of these environmental changes are thought to have occurred because of the building of the Woodruff Dam along the Apalachicola River in 1957 (Schwartz et al., 1995), and changing land uses in the surrounding areas. However, none of these environmental hypotheses have been demonstrated as a cause of the decline. The rapid nature of the decline during the period of 1938 to 1945 and numerous observations of disease symptoms provides ample evidence that a pathogen, possibly non-native, was involved (Schwartz et al., 1995).

\section{Current Status}

The most recent published survey results suggested there are between 800 and 1,500 individual Florida torreya trees in the wild (Schwartz and Hermann, 1993). However, the current number is likely far fewer $(<600)$ (T. Spector, unpublished data), most of which occur on protected lands, but some are on privately held lands. Most of the remaining trees are only stump sprouts between 1 to 3 feet tall and are greatly suppressed. No one has reported seeing any wild seeding from Florida torreya in decades. There is a concerted effort by the Florida Division of Environmental Protection, Florida Park Service, University of Florida and Atlanta Botanical Garden, as well as many concerned volunteer citizens (including small private landowners) to find, record and map each individual to better understand distribution and survivorship of the current trees. Atlanta Botanical Gardens is also propagating Florida torreya using cuttings in order to perpetuate the current individuals, and to produce seed. There are also efforts by researchers in Georgia to use tissue culture and mass produce cloned offspring of Florida torreya. These efforts will be key in restoring the species in its native range once the decline is successfully managed. The Torreya Guardians is a group of private individuals who are transplanting Florida torreya to new localities in the southern Appalachians in an attempt of "assisted migration" (http://www.torreyaguardians.org/). This "assisted migration" takes endemic plants out of their natural range and plants them in private properties and natural gardens. There has been no research into the success or effects of re-introducing Florida torreya on alternate sites and there are risks (i.e. movement of the pathogen(s), potential invasion of the species, reduced focus on preserving the extant population) associated with this approach to conservation (Schwartz, 2005).

The authors have been part of a group (in conjunction with the Atlanta Botanical Garden, Florida Department of Environmental Protection and the Florida Parks Department) assessing the extant Florida torreya populations for the past 3 years. To date, 225 trees have been located and surveyed on public and private lands. The overall condition of the trees is alarming, with an average height of $<1 \mathrm{~m}$, average basal diameter of $<2 \mathrm{~cm}$. Mean canker incidence is about $90 \%$ on 8 sites surveyed (Figs. $4-6$ ). In addition, the existing population is stressed by shading by deciduous tree canopy, leaf spot pathogens (Fig. 7) and an overpopulation of deer - which causes frequent stem damage from rubbing of antlers and occasional browse.

Pathology studies conducted by the authors have shown that a previously unknown Fusarium sp. is the causal agent of the canker disease observed in the field and this has been confirmed from frequent isolation as well as completion of pathogenicity tests (Koch's postulates) in the greenhouse. This disease, though only recently identified, is currently thought to be the single most important factor in Florida torreya decline and potential extirpation. Further information on the biology of the Fusarium canker disease is needed to develop control strategies aimed at reducing the disease on extant populations and also on re-introduced 
individuals from ex situ collections and breeding (at the Atlanta Botanical Garden). There are currently no options for management of any of the diseases affecting Florida torreya.

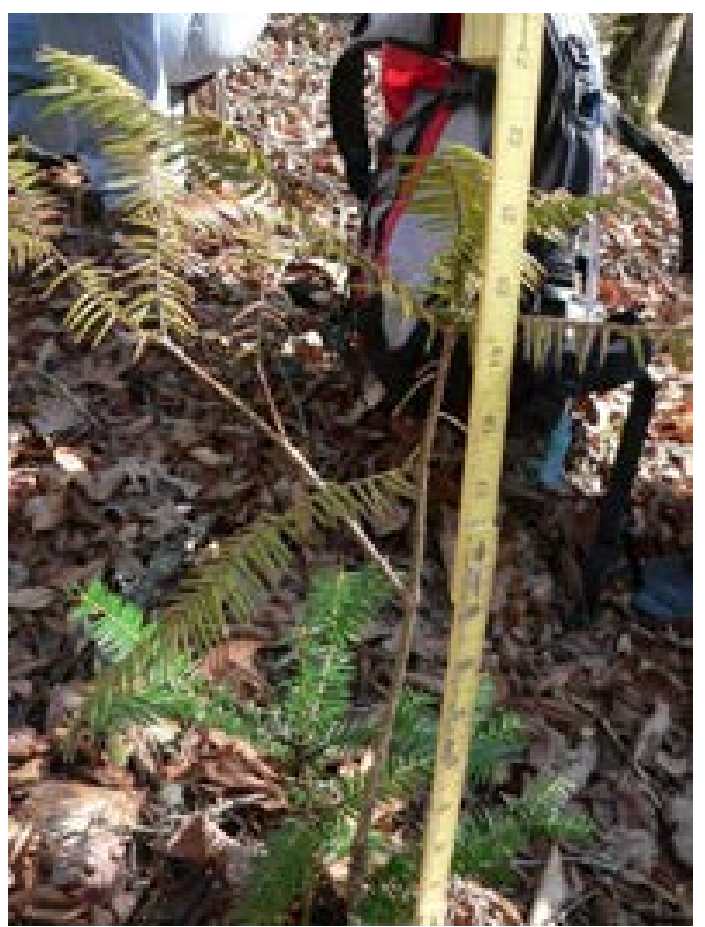

Figure 4. Stump sprout with top killed by canker disease in the wild.

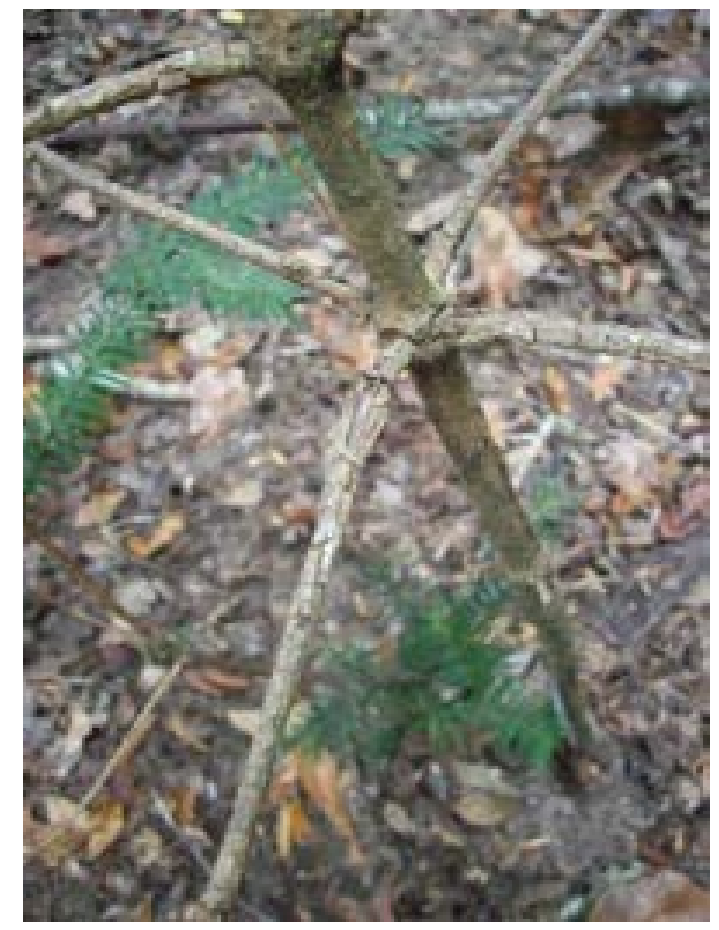

Figure 5. Cankers causing branch dieback on Torreya taxifolia (Photo Credit: Lacey Mount).
Although Florida torreya has been in Florida for over 10,000 years, it continues to be on the brink of extinction. Less than $1 \%$ of the historic population survives, and reproduction of Florida torreya is nonexistent in wild populations (Schwartz and Hermann, 1993). Further research is needed to rescue this ice age relic from extinction.

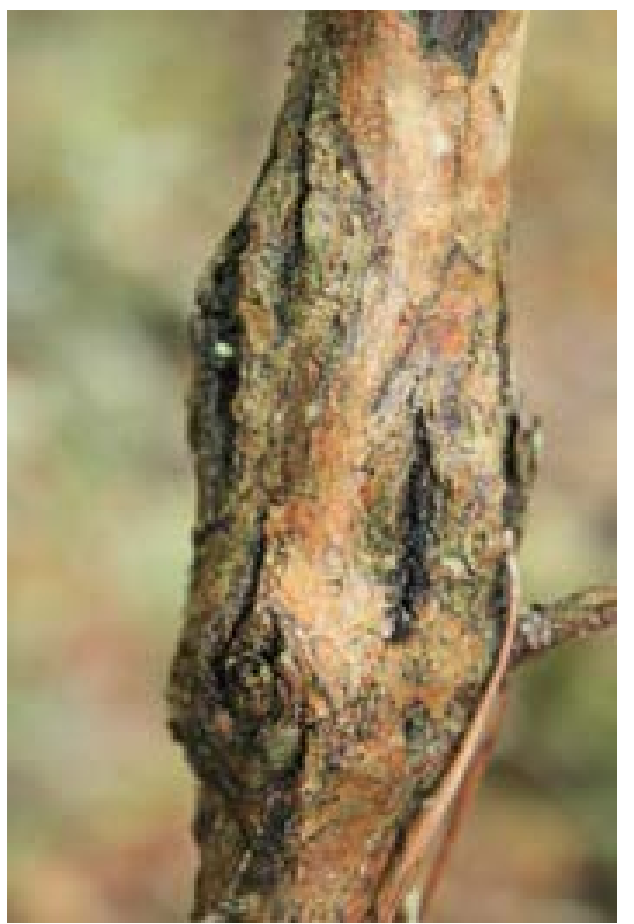

Figure 6. Close-up of canker in the wild (Photo Credit: Matthew (roxton):

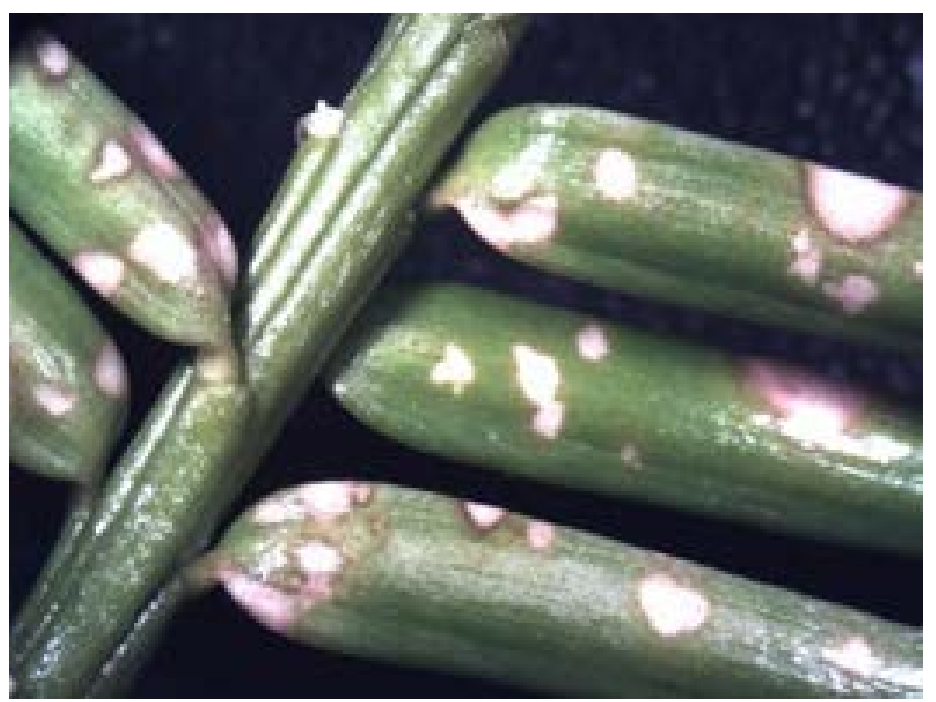

Figure 7. Leaf spots on Torreya taxifolia from unknown agent(s) (Photo Credit: Keumchul Shin). 


\section{References}

Alfieri, S. A., A. P. Martinez, and C. Wehlburg. 1967. Stem and needle blight of Florida torreya, Torreya taxifolia Arn. Proceedings Florida State Horticultural Society 80:428-431.

Alfieri, S. A, C. L. Schoulties, K. R. Langdon, and N. E. El-Gholl. 1987. Leaf and stem disease of Torreya taxifolia in Florida. Florida Dept. Agric. \& Consumer Serv. Plant Pathology Circular No. 291.

Baker, W. and S. Leonard. 1982. A distribution survey of Taxus floridana and Torreya taxifolia in Florida. Unpublished report. U.S. Fish and Wildlife Service.

Barnes, L. 1983. Morphology of Torreya taxifolia Arn. Dept. of Ornamental Hort. Univ. of Florida, Gainesville.

Burns, R. M., and B. H. Honkala, tech. coords. 1990. Silvics of North America: 1. Conifers; 2. Hardwoods. Agriculture Handbook 654. U.S. Department of Agriculture, Forest Service, Washington, DC. vol.2, 877 p.

El-Gholl, N. E. 1985. Fusarium lateritium causing needle spots on Torreya taxifolia in Florida. Plant Disease 69: 905.

Farjon, A. 2010. A handbook of the world's conifers. Brill Academic Publishing. Leiden, The Netherlands. 1112 pp.

Godfrey, R. K. and H. Kurz. 1962. The Florida torreya destined for extinction. Science. 136:900-902.

Lee, J. C., Y. Xianshu, M. W. Schwartz, G. Strobel, and J. Clardy. 1995. The relationship between an endangered North American tree and endophytic fungus. Chemistry \& Biology 2:721-727.

Schwartz, M. W. and S. M. Hermann. 1993. The continuing population decline of Torreya taxifolia Arn. Bulletin of the Torrey Botanical Club 120 (3), 275-286.
Schwartz, M. W., S. M. Hermann, and C. Vogel. 1995. The catastrophic loss of Torreya taxifolia: assessing environmental induction of disease hypotheses. Ecological Applications $5,501-516$.

Schwartz, M. W., S. M. Hermann, and P. J. van Mantgem. 2000. Population persistence in Florida torreya: Comparing modeled projections of a declining coniferous tree. Conservation Biology 14: 1023-1033.

Schwartz, M. W. 2005. Conservationists should not move Torreya taxifolia. Wild Earth 14:72-79.

Sinclair, W. A., H. H. Lyon, and W. T. Johnson. 2005. Diseases of trees and shrubs, 2nd Edition. Cornell University Press, Ithaca, New York. 574 pp.

Spector, T. 2009. Florida Park Service Management Plan for Torreya taxifolia and Taxus floridana. Florida Park Service, May, 2009.

Spector, T. 2010. Florida Department of Environmental Protection, May, 2010. Personal communication.

Stalter, R. and S. Dial. 1984. Environmental status of the stinking cedar, Torreya taxifolia. Bartonia 50: 40-42

USFWS (United States Fish and Wildlife Service) 1984. Endangered and threatened wildlife and plants: final rule to determine Torreya taxifolia (Florida torreya) to be an endangered species. Federal Register 49(2783-2786).

USFWS (United States Fish and Wildlife Service) 1986. Florida torreya Torreya taxifolia recovery plan. U.S. Fish and Wildlife Service, Atlanta, GA. 